\title{
INCIDENCE OF MUSCULOSKELETAL INJURIES IN SOCCER REFEREES: A THREE-YEAR STUDY
}

INCIDÊNCIA DELESÕES MUSCULOESQUELÉTICAS EMÁRBITROS DEFUTEBOL:ESTUDO DE TRÊS ANOS

INCIDENCIA DE LESIONES MUSCULOESQUELÉTICAS EN ÁRBITROS DE FÚTBOL: ESTUDIO DE TRES AÑOS

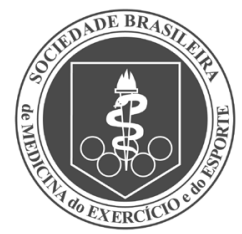

Systematic Review Article Artigo de ReVISÃo SISTEMÁtICA ARtículo de REVISIÓN SISTEMÁtICA
Paulo Rogério Vieira

(Physiotherapist)

Angelica Castilho Alonso ${ }^{2}$

(Physiotherapist and physical

education professional)

Sheila Jean McNeill Ingham

(Physician)

Acary Souza Bulle Oliveira

(Physician)

Beny Schmidt'

(Physician)

Flávio Fallopa

(Physician)

1. Universidade Federal do Estado de São Paulo (UNIFESP), Sao Paulo, SP, Brazil.

2. Faculdade de Medicina da Universidade de São Paulo (USP), Sao Paulo, SP, Brazil.

\section{Correspondence:}

Paulo Rogério Vieira

Rua do Tatuapé, 486, Maranhão, Sao

Paulo, SP. Brazil. 03089-030.

progeriovieira@uol.com.br

\section{ABSTRACT}

Objectives: To determine the incidence and intensity of pain and the areas most affected by injuries with musculoskeletal pain, and the incidence and severity of "injuries defined by time of leave" in games and training of soccer referees in a triennium. Methods: An interview was conducted with 257 referees using a web application. With this tool, a monthly evaluation form was sent to the referees with questions that measured the incidence, location, and pain intensity of injuries with complaints of pain and time of leave, severity in games and training in the years 2012,2013, and 2014. The numerical pain scale was used to classify the pain intensity of the lesions with pain complaint. Results: There was no difference between the years studied in relation to injuries with pain complaints, both in games and in training. Mean values were 37.8/1,000 hours in games and 39.9/1,000 hours in training, with a mean incidence of "injuries defined by time of leave" of 3.7/1,000 hours in games. The difference was significantly higher in 2013 compared to 2012 and 2014, and in training, the average incidence was 3.5/1,000 hours, with a significantly higher difference in $2012 \mathrm{com}$ pared to 2013 and 2014. Conclusion: Lesions with pain complaints did not present a significant difference in games compared to training; in the lesions by time of leave, the incidence in games was higher than in training, and the most frequent type of injury was low-degree muscle pain, predominantly in the thigh and triceps surae. Level of Evidence Il; Prognostic Study - Investigating the Effect of Patient Characteristics on Disease Outcome.

Keywords: Injuries; Soccer; Musculoskeletal pain.

\section{RESUMO}

Objetivos: Determinar a incidência e a intensidade álgica e os locais mais acometidos por lesões com dor musculoesquelética e incidência e gravidade das "lesões definidas por tempo de afastamento" em jogos e treinos de árbitros de futebol, em um triênio. Métodos: Foram entrevistados 257 árbitros utilizando-se um aplicativo da web. Com essa ferramenta, foi enviada aos árbitros uma ficha de avaliação mensal com questões que mediam incidência, localização e intensidade álgica das lesões com queixas de dor e por tempo de afastamento, gravidade em jogos e treinos nos anos de 2012, 2013 e 2014. Para classificar a intensidade álgica das lesões com queixas utilizou-se a escala numérica de dor. Resultados: Não houve diferença entre os anos estudados com relação às lesões com queixas de dor, tanto em jogos quanto em treinos. Os valores médios foram de 37,8/1.000 horas em jogos e 39,9/1.000 horas em treinos e a incidência média de "lesões definidas por tempo de afastamento" de 3,7/1.000 horas em jogos. A diferença foi significantemente maior em 2013 com relação a 2012 e 2014 e, em treinos, a incidência média foi de 3,5/1.000 horas com diferença significantemente superior em 2012 com relação a 2013 e 2014. Conclusão: As lesões com queixas de dor não apresentaram diferença significante em jogos comparados com treinos; nas lesões por tempo de afastamento, a incidência em jogos foi maior do que em treinos, e o tipo de lesão mais frequente foi a muscular de grau leve, predominando na coxa e no tríceps sural. Nível de evidência II, Estudos diagnósticos - Investigação de um exame para diagnóstico.

Descritores: Lesões; Futebol; Dor musculoesquelética.

\section{RESUMEN}

Objetivos: Determinar la incidencia y la intensidad del dolor y los lugares más afectados por lesiones con dolor musculoesquelético e incidencia y gravedad de las "lesiones definidas por tiempo de licencia" en juegos y entrenamientos de árbitros de fútbol en un trienio. Métodos: Fueron entrevistados 257 árbitros utilizando una aplicación de la web. Con esta herramienta, se envió a los árbitros una ficha de evaluación mensual con cuestiones que median incidencia, localización, intensidad de las lesiones con quejas de dolor y por tiempo de licencia, gravedad en juegos y entrenamientos en los años 2012, 2013 y 2014. Para clasificar la intensidad del dolor de las lesiones con quejas se utilizó la escala numérica de dolor. Resultados: No hubo diferencia entre los años estudiados en relación a las lesiones con quejas de dolor, tanto en juegos como en entrenamientos. Los valores promedio fueron de 37,8/1.000 horas en juegos y 39,9/1.000 horas en entrenamientos, siendo la incidencia media de "lesiones definidas por tiempo de licencia" de 3,7/1.000 horas en juegos. La diferencia fue significantemente mayor en 2013 con respecto a 2012 y 2014 y en los entrenamientos, la incidencia media fue de 3,5/1.000 horas 
con una diferencia significantemente superior en 2012 con respecto a 2013 y 2014. Conclusión: Las lesiones con quejas de dolor no presentaron diferencia significativa en juegos comparados a los entrenamientos; en las lesiones por tiempo de licencia, la incidencia en juegos fue mayor que en entrenamientos, y el tipo de lesión más frecuente fue la muscular de grado leve, predominio en el muslo y tríceps sural. Nivel de evidencia II, Estudios de diagnósticos - Investigación de un examen para diagnóstico.

Descriptores: Lesiones; Fútbol; Dolor musculoesquelético.

\section{INTRODUCTION}

In a soccer match, the referee performs physical activities similar to those of the midfield athlete. However, he is on average 15 years older than the player, has no physical contact with the ball, neither with the opponent, causing a pattern of movement with less risk of traumatic injuries and greater risk of injuries due to overuse. ${ }^{1,2}$ In addition to this, in the world, referees' condition of activity is amateur and is not a regulated profession compared to professional soccer players and this may reduce the possibilities of physical and psychological preparation, as well as in the prevention and treatment of injuries. ${ }^{3}$

This scenario shows the inequalities of conditions and justify the differences regarding the profile of musculoskeletal injuries between the two groups. The few studies done on musculoskeletal injuries in referees have many methodological differences, but the results have shown that traumatic injuries are rare and that most injuries in referees were caused by a repetitive strain mechanism producing injuries due to overuse. ${ }^{2,45}$ In Brazil, there is only one study on injuries in referees involving the FIFA test. ${ }^{6}$

Several authors have pointed to the need for consensus in standardization, not only for the definition of the injury, but also in the study design, data collection and procedures. ${ }^{1,7}$ Historically, studies about the incidence of injuries in professional soccer use the definition of time-loss injury. We must consider that less serious damages and those due to overuse, without lost time, add up to the majority of the cases and are, consequently, underestimated and unregistered. ${ }^{2}$

Therefore, since soccer is one of the most popular sports in the world and specifically in Brazil, the large number of teams, games and, consequently, the number of referees, this study is justified and there is a need for a more adequate assessment methodology for this population.

The objective of this study is to check the incidence, pain intensity and sites most affected by injuries with musculoskeletal pain and the incidence and severity of "time-loss injuries" from games and training sessions, among soccer referees from Federação Paulista de Futebol between 2012 and 2014

\section{METHODS}

This is a prospective cross-sectional study approved by the Research Ethics Committee of Universidade Federal de São Paulo no. 1898/10. All participants accepted to participate in the study and signed an Informed Consent Form.

\section{Study sample}

Professional soccer referees were studied with the following inclusion criteria: being a referee registered in Federação Paulista de Futebol (FPF) and have had their annual registration approved; being male; being 18 to 45 years old. As exclusion criteria, those who failed to reply to at least seven e-mails out of 12 during the year, both during games and while training.

Figure 1 represents the inclusion of the referees, as well as the concepts of injuries used in the study.

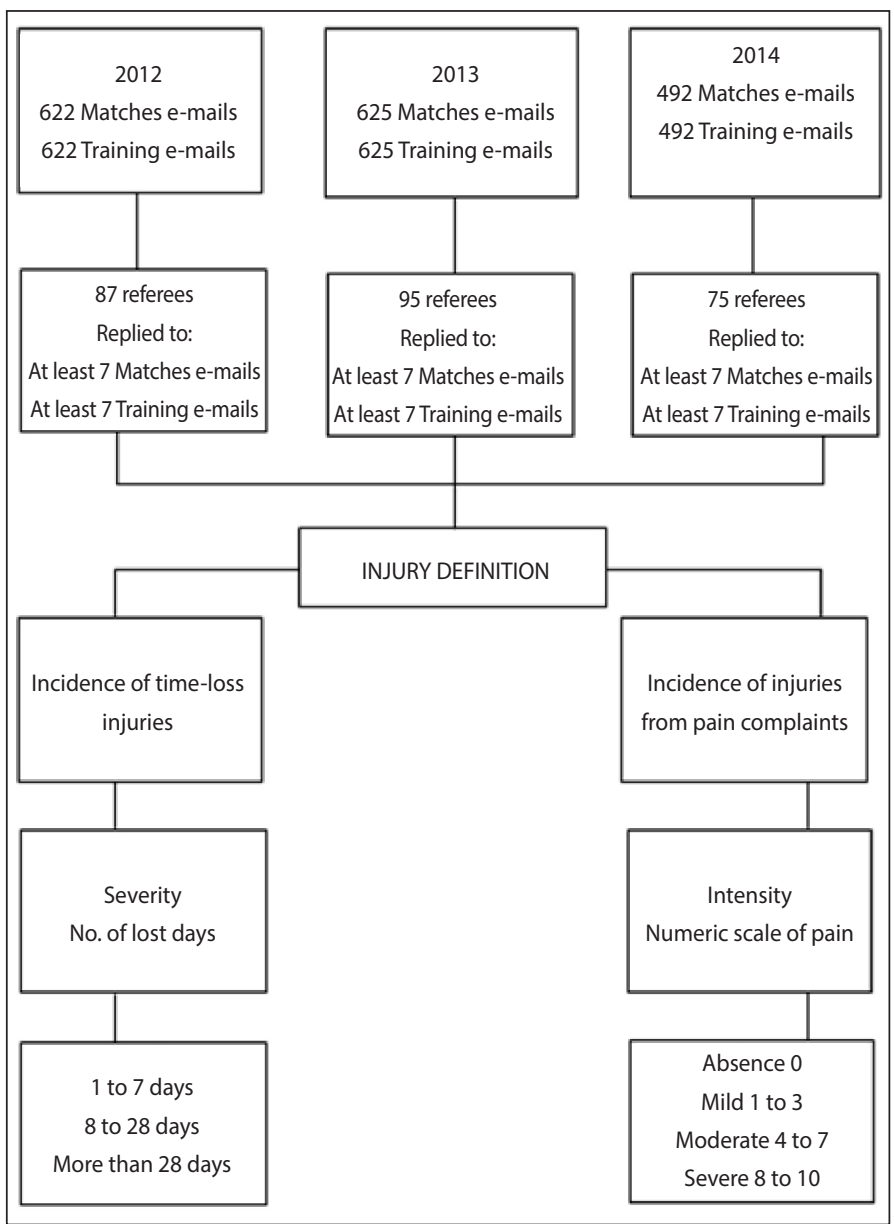

Figure 1. Flowchart of inclusion of referees and injury definitions

\section{Injury definitions}

For this study, we used the following definitions of injuries, which meet the recommendations established by the FIFA medical consensus ${ }^{7}$, described below:

- Injury with interruption of activities in games and/or training is any complaint by a referee that makes him unable to work on a match or a complete training, regardless of the time elapsed since the onset of symptoms. Its severity is measured by the number of days of absence of training activities and/or games, divided into three groups: mild ( 1 to 7 days of absence), moderate (8 to 28 days), severe (more than 28 days). ${ }^{7,8}$

- Injury is any pain complaint sustained by a referee that results from a soccer match or soccer game, irrespective of the need for medical attention or time-loss from soccer activities. ${ }^{7,8}$

\section{Procedures}

To conduct the research, we used a web application available online at www.surveymonkey.com. During the three years of the study, all referees received monthly e-mails with evaluation sheets to investigate the events of the previous month in games and training sessions. 
The evaluation sheets were prepared with questions based on the FIFA medical consensus ${ }^{7}$ and on studies by Bizzini et al., ${ }^{2}$ to measure the incidence, location and pain intensity from the injuries.

Pain intensity was not mentioned in the FIFA consensus, but in this study, it is measured and analyzed using the numeric pain rating scale (NPRS) to record injuries with mild, moderate and severe intensity. It consists of a ruler divided into eleven equal parts numbered from 0 to 10 . It is intended to make the individual match the intensity of the symptom and the numeric classification establishing that zero is absence of pain; 1 to 3 , mild pain; 4 to 7 , moderate pain; 8 to 10 , severe pain. ${ }^{9}$

The location of the injuries was demonstrated by an anatomical model found in assessment sheets, where the referee indicated the location and intensity of the pain.

The incidence of time-loss injuries and their severity were measured were measured by days off refereeing activities, divided in 1 to 7 days; 8 to 28 days and over 28 days in games and training.

\section{Statistical analysis}

The data were stored and analyzed in the program Statistical Package for the Social Sciences (SPSS) 20.0 for Windows and presented on tables and charts. The analysis of injury data was presented in absolute values and the incidence (no. of new injuries/ $\Sigma$ hours of exposure X 1000) and percentage of frequency (no. of injuries/ $\Sigma$ of total injuries X100) was calculated.

The chi-square test was applied to compare the incidences. For the statistical analysis, $\mathrm{p} \leq 005$ was considered significant.

\section{RESULTS}

The 257 referees had a mean age of $32.9 \pm 5.0$ years; body mass of $76.7 \pm 9.6 \mathrm{~kg}$; height of $178 \pm 0.05 \mathrm{~cm}$. The average number of matches refereed weekly was 1.73 match/referee. The refereeing time spent on average was 2h40min/weekly and, in training, 3 h04 min/week.

In matches, there was no significant difference in pain intensities between the years in mild injuries $(x 2=71.0 ; p=0.157)$; severe injuries $(x 2=8.9$; $p=0.177$ ) and total injuries $(x 2=55.8 ; p=0.407)$. However, injuries of moderate intensity in 2014 were significantly higher than in 2013 ( $x 2=15.0 ; p=0.020$ ).

In training sessions, there was no significant difference between the years in mild injuries ( $x 2=54.0 ; p=0.390)$; in severe injuries $(x 2=2.4 ; p=0.663$ ) and in total injuries $(x 2=72.0 ; p=0.230)$. However, moderate injuries were significantly higher in 2012 compared to 2013 ( $x 2=12.0 ; p=0.034$ ).

There was no statistically significant difference between the years studied for matches $(x 2=55.8 ; p=0.407)$, training $(x 2=72,0 ; p=0,230)$ and total injuries $(x 2=57.62 ; p=0.759)$ (Table 1$)$.

The anatomical location of the injuries according to pain complaints in matches and training sessions are reported in Figure 2. There was predominance in lower limbs. The most affected sites in the three years were knee, triceps surae muscle, posterior thigh.

Table 2 compares the incidence of time-loss from injuries in matches, training and in total in each year of the study. In matches, in 2013, they were significantly higher than in $2012(x 2=20.8 ; p=0.014)$ and 2014 $(x 2=24.0 ; p=0.008)$. And in 2012 they were significantly higher than in 2014 ( $x 2=24.0 ; p=0.004$ ). Regarding severity between 1 and 7 days, in 2012, there was a significant bigger difference compared to 2014 $(x 2=24.0 ; p=0.001)$ and, in 2013, the incidence was significantly higher than in 2014 ( $x 2=20.8 ; p=0.002$ ). In moderate injuries, between 8 and 28 days of interruption, 2012 was significantly higher than 2014 ( $x 2=13.0$; $p=0.042$ ) and 2013 was higher than 2014 ( $x 2=14.4, p=0.025)$. Regarding severe injuries, equal to or greater than 28 days, 2014 was higher than 2012 ( $x 2=11.6 ; p=0.009$ ) and 2013 was significantly higher than 2014.

In training sessions, 2012 had a significantly higher incidence than 2013 ( $x 2=24.0 ; p=0.031)$ and $2014(x 2=24.00 ; p=0.031)$. The year 2013 was significantly higher than $2014(x 2=24.00 ; p=0.013)$.
Table 1. Comparisons of pain intensities in referees in the incidence of injuries.

\begin{tabular}{|c|c|c|c|c|}
\hline \multicolumn{5}{|c|}{ Matches } \\
\hline Intensity & $\begin{array}{c}2012 \\
\mathrm{~N} \text { (Incidence) }\end{array}$ & \begin{tabular}{c|}
2013 \\
$\mathrm{~N}$ (Incidence)
\end{tabular} & \begin{tabular}{c|c|}
2014 \\
$\mathrm{~N}$ (Incidence)
\end{tabular} & $p$-value \\
\hline Mild & $416(38.4)$ & $339(29.7)$ & $319(32.6)$ & \\
\hline Moderate & $37(3.4)$ & $20(1.8)^{\S}$ & $51(5.2)^{\S}$ & ${ }^{\S} 2014>2013 p=0.02$ \\
\hline Severe & $8(0.7)$ & $8(0.7)$ & $9(0.9)$ & \\
\hline \multicolumn{5}{|c|}{ Training } \\
\hline Mild & $596(45.9)$ & $443(29.9)$ & $416(32.9)$ & \\
\hline Moderate & $56(4.3)^{*}$ & $20(1.3)^{*}$ & $39(3.1)$ & ${ }^{*} 2012>2013 p=0.03$ \\
\hline Severe & $13(1.0)$ & $10(0.7)$ & $10(0.8)$ & \\
\hline
\end{tabular}
2012 compared to 2013. Chi-square test; $p \leq 0.05$.

A Sites with higher incidence of complaints in matches

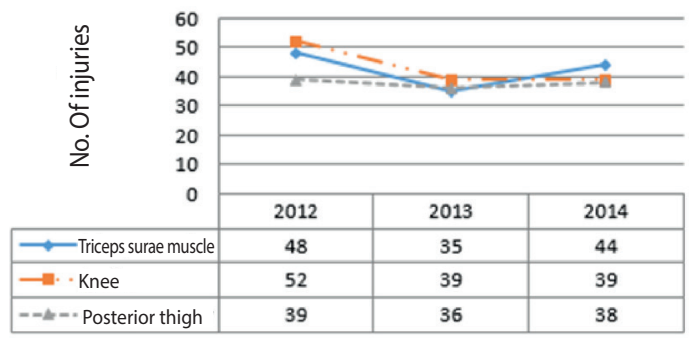

Anatomical sites most affected in matches

B

Sites with higher incidence of complaints in training

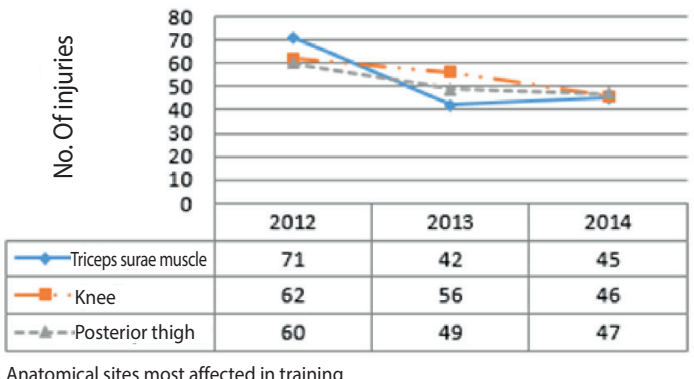

Anatomical sites most affected in training

Figure 2. Anatomical sites most affected by complaint in matches (a) and training (b).

Table 2. Severity of injuries measured by days off matches and training among referees [mean (standard deviation)].

\begin{tabular}{|c|c|c|c|c|}
\hline \multicolumn{5}{|c|}{ Matches } \\
\hline Severity & $\begin{array}{c}\text { N incidence } \\
2012 \\
\end{array}$ & $\begin{array}{c}\mathrm{N} \text { incidence } \\
2013 \\
\end{array}$ & $\begin{array}{c}\text { N incidence } \\
2014\end{array}$ & $p$-value \\
\hline 1 to 7 days & $28(2.5)^{\#}$ & $24(2.1)^{\S}$ & $11(1.1)^{\# \S}$ & $\begin{array}{l}\# 2012>2014 p=0.001 \\
\S 2013>2014 p=0.002\end{array}$ \\
\hline 8 to 28 days & $13(1.2)^{\#}$ & $14(1.2)^{\S}$ & $7(0.7)^{\# \S}$ & $\begin{array}{l}{ }^{\#} 2012>2014 p=0.042 \\
\S 2013>2014 p=0.025\end{array}$ \\
\hline$>28$ days & $4(0.3)^{\#}$ & $12(1.0)^{5}$ & $10(1.0)^{\# \S}$ & $\begin{array}{l}\# 2012<2014 p=0.009 \\
\S 2013>2014 p=0.010\end{array}$ \\
\hline Total & $45(4.1)^{* \#}$ & $50(4.3)^{* 5}$ & $50(4.3)^{* 5}$ & $\begin{array}{l}* 2012<2013 p=0.014 \\
\# 2012>2014 p=0.004 \\
\S 2013>2014 p=0.008\end{array}$ \\
\hline \multicolumn{5}{|c|}{ Training } \\
\hline 1 to 7 days & $35(2.7)^{* \#}$ & $22(1.4)^{* \xi}$ & $18(1.4)^{\# \S}$ & $\begin{array}{l}{ }^{*} 2012>2013 p=0.021 \\
{ }^{\#} 2012>2014 p=0.042 \\
{ }^{\S} 2013>2014 p=0.004\end{array}$ \\
\hline 8 to 28 days & $13(1.0)$ & $15(1.0)^{\S}$ & $8(0.6)^{5}$ & ${ }^{5} 2013>2014 p=0.025$ \\
\hline$>28$ days & $5(0.3)^{*}$ & $8(1.2)^{* \S}$ & $10(0.7)^{\S}$ & $\begin{array}{l}{ }^{*} 2012<2013 p \leq 0.001 \\
\S 2013>2014 p=0.001\end{array}$ \\
\hline Total & $53(4.0)^{* \#}$ & $45(3.7)^{*} \S$ & $36(2.8)^{\# \S}$ & $\begin{array}{l}{ }^{*} 2012>2013 p=0.031 \\
{ }^{*} 2012>2014 p=0.031 \\
{ }^{\S} 2013>2014 p=0.013\end{array}$ \\
\hline
\end{tabular}

*significant difference in the comparison between 2012 and 2013. \# significant difference in the comparison between 2012 and 2014. $§$ significant difference in the comparison between 2013 and 2014. Chi-square test; $p \leq 0.05$. 
Regarding mild injuries, with interruption between 1 and 7 days, in 2012, there was a significantly greater difference than 2013 ( $x 2=21.00$; $p=0.021)$ and $2014(x 2=16.00 ; p=0.042)$. The year 2013 presented a significantly greater difference compared to 2014 ( $x 2=21.00 ; p=0.004)$. As for the moderate lesions between 8 and 28 days, 2013 was significantly higher than 2014 ( $x 2=14.40 ; p=0.025$ ). Severe time-loss with more than 28 days of interruption were significantly higher in 2013 than in 2012 ( $x 2=20.50 ; p \leq 0.001)$ and in 2014 ( $x 2=20.66 ; p=0.001)$.

\section{DISCUSSION}

In this study, there was a certain homogeneity of results with mild and frequent injuries, both in injuries with pain complaints and in injuries causing time-loss from matches and training. These findings were similar to other studies, ${ }^{4,5}, 10-12$

The incidences of pain complaints, in matches and training, were higher than other studies, due to the characteristics of their definition. Wilson et al..$^{5}$ and Kordi et al. ${ }^{11}$ presented lower rates than this study. Bizzini et al. ${ }^{10}$ also presented lower rates. However, the authors analyzed the prevalence of injuries with pain complaints and, therefore, such study does not allow comparison with incidence studies.

There was a predominance of injuries with complaints of mild pain, demonstrating that any other type of injury definition would lead to underreporting of these episodes, as they rarely lead to time-loss. Bizzini et al. ${ }^{2}$ argue that the referees do not have any physical contact and do not reach the same intensity in the movements of acceleration and deceleration in the matches compared to the athletes, as they only need to stand close to the playing action.

There was predominance of thigh, triceps, and knee injuries, both in matches and in training, which is similar to other studies. $4,5,10,11$ This is probably due to changes of direction, medium and high-intensity runs, leading the posterior muscle chain to undergo constant eccentric loads, and knees and ankles are required in rotational movements. Besides that, Bizzini et al. ${ }^{2}$ argue that back-and-forth runs, often seen in referees' activities, involve muscle activity per unit of force applied to the ground $10 \%$ higher than forward runs, and also produce an additional energy expenditure of $20 \%$, which can create considerable overload in the triceps surae muscle and in the calcaneus tendon., 2,13,14

The posterior, anterior, medial, lateral thighs, together, outnumbered all other locations. Muscle injuries, especially in the posterior thigh, are usually non-contact injuries, mainly due to previous injuries, biomechanical imbalances of agonist/antagonist muscles and explosive activities at high speeds. .,12,15,16 $^{-16}$

When the intensity of pain exceeds bearable levels associated with other signs and symptoms inherent in each injury, mainly with functional disability, there is time-loss of refereeing activities. With this concept, the number of time-loss injuries was much lower than the number of injuries with pain complaints.

Comparing the time-loss injuries, in 2013, we had a peak in the number of match interruptions. In training, the highest number was in 2012 and both fell significantly in 2014. Perhaps the decrease in the number of injuries was due to a potential random adjustment of training loads and matches. According to Gabbet et al., ${ }^{17}$ the influence of training volume and how they are conducted may influence the risk of injury, and not always the reduction in training loads may be the best course of action in injury prevention. Weston et al. ${ }^{3}$ concluded that structured programs with intermittent high-intensity training sessions can significantly increase the level of physical fitness of this population.
These and other aspects may have qualified the referee better, causing a decrease in the number of occurrences. This qualification may come from a more responsible population that responded to e-mails during the years of the research, creating a more participatory group aware of the general recommendations, such as training schedules suggested by the physical department of the FPF, body mass awareness, and nutrition. Another aspect may be related to the World Cup in Brazil in 2014, which was a relevant event in this period, because in addition to the example shown by the participation of the best referees in the world, there was a one-month interruption during the event of all championships, creating a rest period.

In the three years of the study, there was an average incidence of injuries per lost time of 3.7/1000 hours in matches and 3.5/1000 hours in training. In the 2006 World Cup, Bizzini et al. ${ }^{10}$ pointed out an incidence of injuries about five times greater in matches (20.8/1000 h) than in this study. This discrepancy could be justified by a different data collection technique or by the presence of a medical team prepared to provide medical care and record the injuries in a short high-competitive tournament, with referees older than 40 . Wilson et al. ${ }^{5}$ also had a higher incidence (16.8/1000 h) in matches despite having also used a website. The data collection technique was done weekly by e-mail. If an injury was recorded, the referee was phoned by an investigator within three days. In the study by Kordi et al. ${ }^{11}$, the incidence was 19.6/1000 hours, and this disparity can be justified by the data collection technique that was done weekly by two physicians by telephone.

The severity of the time-loss injuries classified as mild, which took from 1 to 7 days of interruption, prevailed both in matches (51.2\%) and in training sessions (56\%), which is similar to Wilson et al. ${ }^{5}$, in which mild injuries prevailed. However, Kordi et al. ${ }^{11}$ found that most of the injuries were moderate with interruptions of 8 to 28 days. Bizzini et al. ${ }^{10}$ mentioned that no referee had any time loss in the 2006 World Cup; they only modified their activities in training.

The referee is the only non-professional participant, with no category regulation, with little structure in physical or psychological preparation, and medical treatment and recovery are generally inadequate. Gabrilo et al. ${ }^{12}$ argued that international referees from the Union of European Football Associations (UEFA) had lower injury rates than national referees in Croatia because of better physical training, regular medical care and greater professionalism.

The limitations of the study were due to the low number of responses to e-mails by referees and self-reported injuries, the difficulty of obtaining medical diagnosis and adequate records in a large population distributed throughout the state of São Paulo. However, this is the first study with these characteristics in Brazil.

\section{CONCLUSION}

The incidences of injuries with pain complaints did not present any significant difference in matches (37.8/1000 hours) compared to training sessions (39.9/1000 hours).

The incidence of "time-loss injuries"was higher in matches (3.7/1000 hours) than in training (3.5/1000 hours).

The most frequent type of mild muscular injury especially in the thighs, knees and triceps surae muscle.

All authors declare no potential conflict of interest related to this article

AUTHORS' CONTRIBUTIONS: Each author made significant individual contributions to this manuscript. PRV (0000-0000-0000-0000)*: writing the article, revision, data collection and preparation of the entire research project; ACA (0000-0002-9644-5068)*: analysis of the data and writing the article; SJMI (0000-0003-2072-1094) revision of the article; ASBO (0000-0002-6986-4937): revision of the article and intellectual conception of the article; BS (0000-0002-4966-3628)*: revision of the article and also the whole intellectual conception of the article; FF (0000-0000-0000-0000) intellectual conception of the article and preparation of the entire research project. ${ }^{*} \mathrm{ORCID}(\mathrm{Open}$ Researcher and Contributor ID). 


\section{REFERENCES}

1. Junge A, Dvorak J. Influence of Definition and Data Collection on the Incidence of Onjuries in Football. Am J Sports Med. 2000;28(5 Suppl) :S40-6.

2. Bizzini $M$, Junge $A$, Bahr R, Dvorak J. Injuries and musculoskeletal complaints in referees a complete survey in the top divisions of the swiss football league. Clin J Sport Med. 2009;19(2):95-100.

3. Weston M, Helsen W, MacMahon C, Kirkendall D. The Impact of Specific High-Intensity Training Sessions on Football Referees'Fitness Levels. Am J Sports Med. 2004;32(1 Suppl):54S-61S.

4. Brukner P, Khan KM, Carliste J. Comparison of significant injuries in AFL players and umpires. Aust J SCi Sports Med. 1991;23:21-3.

5. Wilson F, Byrne A, Gissane C.A prospective study of injury and activity profile in elite soccer referees and assistant referees. Ir Med J. 2011; 104(10):295-7.

6. Silva Al, Paes MR. Lesões ocorridas em árbitros de futebol da CBF durante a partida, treinamento e teste físico. Fisiot. Brasil. 2011; 12(4):267-72.

7. Fuller CW, Ekstrand J, Junge A, Andersen TE, Bahr R, Dvorak J, Hägglund M, McCrory P. Meeuwisse WH Consensus Statement on Injury definitions and data collection procedures in studies of football (soccer) injuries. Br.J Sports Med. 2006;40(3):193-201.

8. Hägglund $M$, Waldén $M$, Bahr R, Ekstrand J. Methods for epidemiological study of injuries to professiona football players: developing the UEFA model. Br J Sports Med. 2005;39(6):340-6.
9. Carlson AM. Assessment of chronic pain. Aspects of the Reliability and Validity of the Visual Analogue Scale. Pain. 1983,16(1):87-101.

10. Bizzini M, Junge A, Bahr R, Helsen W, Dvorak J. Injuries and musculoskeletal complaints in referees and assistant referees selected for the 2006 FIFA Word Cup: retrospective and prospective survey. $\mathrm{Br}\rfloor$ Sports Med. 2009;43(7):490-7.

11. Kordi R, Chitsaz A, Rostami M, Mostafavi R, Ghadimi M.Incidence, nature, and pattern of injuries to referees in a premier football (soccer) league: a prospective study. Sports Health. 2013;5(5):438-41.

12. Gabrilo G, Ostojic M, Idrizovic K, Novosel B, Sekulic D. A retrospective survey on injuries in Croatian football/soccer referees. BMC Musculoskelet Disord. 2013;14:88

13. Castagna C, Abt G, D'Ottavio S. Physiological Aspects of Soccer Refereeing Performance and Training. Sports Med. 2007;37(7):625-46.

14. Reilly T, Gregson W. Special population: the referee and assistant referee J Sports Sci. 2006;24(7):795-801.

15. Askling C, Karlsson J, Thorstensson A.Hamstring injury occurrence in elite soccer players after preseason strength training with eccentric overload. Scand J Med Sci Sports. 2003;13(4):244-50.

16. Arnalson A, Gudmundsson A, Dahl HA, Jóhannsson E. Soccer injuries in Iceland. Scand .J Med Sc Sports. 1996;6(1):40-5

17. Gabbet TJ. The training-injury prevention paradox: should athletes be training smarter and harder? Br J Sports Med. 2016;50(5):273-80. 